\title{
THE PERSONALITY OF MAIN CHARACTER IN THE FILM SERIES NOBUTA WO PRODUCE BY IZUMI KIZARA (A CARL GUSTAV JUNG'S PSYCHOANALYTIC APPROACH)
}

\author{
Nurfitiani Nuriman ${ }^{1}$, Emzir $^{2}$ \\ Universitas Negeri Jakarta ${ }^{12}$ \\ nurfitriani.nuriman@unj.ac.id ${ }^{1}$, emzir.unj@unj.ac.id ${ }^{2}$
}

\begin{abstract}
This research aimed to obtain a deep depiction of personality type on the main character in the film series: Nobuta wo Produce by Izumi Kizara. Film series Nobuta wo Produce is a television drama series adapted from novel with the same title by Gen Shiraiwa. This research was conducted using content analysis method. This research data was analyzed through psychoanalytic by Carl Gustav Jung approach. The data were collected through documents, and data observations about the main character personality in film series: Nobuta wo Produce by Izumi Kizara. The result showed that Kiritani Shuuji as the main character of film series: Nobuta wo Produce by Izumi Kizara has two tendencies of the dominant personality type, thinking introvert type and feeling ekstravert type. The result lead to recommendation to Japanese literature educator, literature researcher, film review, and parents.
\end{abstract}

Keywords: Personality type, film as literature, psychoanalysis, Carl Gustav Jung.

Film is the first mass communication media that combines visual and audiovisual effects. In addition to function as entertainment, in its development the film is also often used as a propaganda media, even educational socialization (Trianton 2013: 59). In the field of study of foreign language education in universities, especially in the Department of Japanese Language Education, State University of Jakarta, film is often used in linguistic subjects, but the use of film as a literary work is still rare. Research on films is only about linguistic research. In fact, film is also one form of literary works that can be studied with literary approach, and can provide more value to our linguistic knowledge. Because studying film as part of a literary work not only improve knowledge of literature but also deepens language experience through the dialogues of the characters presented in the film.

Film as a product of literary works is described by Klerer. He said that originally in the 20th century, it is difficult to deny the existence of the film as part of a kind of literary work that has a semi-textual genre that both inspires and influences literary science and literary criticism. Literary works in the form of fictional films eventually are declared as a category of literary works based on the effects generated for the audience, it can also be categorized into films of modern drama performances that can be displayed as intact performances that meet the criteria of important elements of the work of fiction. Although the film has specific characteristic and terminology specifications, but it is possible to be studied using literary criticism, film criticism is strongly associated with traditional approaches in textual studies. Meanwhile, literary approaches such as psychoanalytic theory or feminism theory can be used as a framework for film review (Klerer 2005: 56).

Psychology of literature is a literary study that views work as a psychological activity. Psychology of Literature recognizes literature as a psychic reflection. The author will capture the phenomena of the soul and then processed into the text and equipped with psychiatric. The projection of self-experience and the experience of living around the author, will be projected imaginatively into literary texts. A literary work that is seen as a psychological phenomenon, will display psychological aspects through characters if by chance the text is a drama or prose (Endraswara 2011: 96). According 
to Wellek, Warren, and Hardjana there are four possibilities of literature psychology research, that is research on psychology authors as individuals, creative process research in relation to psychology, psychology law studies applied to literary works, the last is the study of the psychological effects of literary texts to the reader (Endraswara 2011: 98). In this study, researchers will examine the laws of psychology applied to literary works in the form of film, namely: a study directed to the theory of analytical psychology Carl Gustav Jung into a literary text in the form of film.

Referring to Wellek's opinion, quoted in Siswantoro, the psychological type and psychological laws that are present in literature emphasize psychological analysis directed at the main character, because the most intense types and laws of psychology are present in the main character of the most exposed to conflict rather than other characters, this research is directed to the personality of the main character (2005: 86). As for that, it takes a film with the main character who experienced the development of personality as a source of research data. Based on these considerations, the researchers chose the film series titled Nobuta wo Produce by Izumi Kizara for analysis using psychoanalytical approach Carl Gustav Jung.

The film series Nobuta wo Produce by Izumi Kizara is the result of ecranisation extract from a novel of the same title by Gen Shiraiwa. The series of ten episodes was produced and aired in 2005 by NTV (Nihon Television Network). This film tells about the friendship of three high school students, namely Shuji Kiritani, Akira Kusano and Nobuko Kotani. Shuji Kiritani is one of the most popular students in his school. Shuji treats everything in his life as a game, therefore, he lives with lies. He believes that by maintaining a "cool" character he can achieve his goal of life without any obstacles.

In connection with the film series Nobuta wo Produce by Izumi Kizara, there are international journals with the title “小説 野ブタ。をプロデュース」に見る自己 (ペルソナと自己プロデュース )” by Nakamura and Tomoko in 2013. This study examines Shuuji's mental and interpersonal relationship as the main character in Nobuta wo Produce's novel by Gen Shiraiwa, http://ir.tokyokasei.ac.jp/meta-bin/mt-pdetail.cgi?cd $=00002733$. The results of the study in this international journal show that Shuuji has some narcissistic disorder. For example, he made a great deal of effort to maintain his strong persona. Although Shuuji seems to have a good relationship with friends and family, his strong persona actually prevented him from having close relations with others. Therefore, Nobuta wo Produce film series by Izumi Kizara is the result of an ecranisation from novel with the same title by Gen Shiraiwa. This film series full of psychological aspects of the main character that worthy of being studied using psychoanalytical approach Carl Gustav Jung.

The research that examines the phenomenon depicted in the main characters also appear in "Characterization of Woman Widowed in the Short Story Namanya, Massa, Tarian Hamil dan Penyair Bulan, and Norhayati (Literary Review Cross Reference) by Purnomosidhi and Lustyantie, doi.org/10.21009/BAHTERA.171.9. This study is a cross reference study based on the theory of literary sociology to obtain relationships between literature and society through the main characters in three different short stories about women widow, while in this personality research examines the psychological aspects contained in the main character, namely personality types of the main character.

The relevance of this study also appears in the article "Self-Actualization of the Main Character in Novel Pasung Jiwa by Okky Madasari (A Literary Psychoanalytic Research)" by Husada, Nuruddin, and Lustyantie, https://doi.org/10.21009/BAHTERA.162.02. This study is relevant because it equally analyzes the psychological aspects of the main character in fiction, but the literary psychology approach used in Husada, Nuruddin, and Lustyantie study is based on Sigmund Freud's psychoanalysis to study self-actualization of the main character, while in this personality research using Carl Gustav Jung's psychoanalytic approach to examine personality types of the main character on the film series.

The relevance of subsequent research is in an article entitled "Racial Discrimination in The

Help Works of Tate Taylor (Feminism Approach)" by Ariesta,


https://doi.org/10.21009/BAHTERA.162.04 . This study analyzes the forms of racial discrimination and the efforts undertaken by female lead characters in films in the face of racial discrimination. Although this study is a study of feminism, it is equally a qualitative study that examines the phenomena found in the main characters in the film.

The study of personality used Carl Gustav Jung's psychoanalytic approach has been done in the article with the title "Personality Dynamics of Main Characters in the Novel Hubbu by Mashuri's Work Based on Jung's Perspectives " by Rahmawati, http://dx.doi.org/10.17977/jph.v1i2.4054. This study is relevant to personality research in this article. Rahmawati examines the progression and personality regression of the main characters in Hubbu novel by Mashuri. This research is relevant because they examine the personality from with psychoanalytical perspectives of Carl Gustav Jung. The difference between these two studies is that Rahmawati emphasizes the personality dynamics of the main character Jarrot (personality progression and regression of the main characters) in Hubbu novel by Mashuri, meanwhile the focus in this personality study is to emphasizes the main character personality types in the film series Nobuta wo Produce by Izumi Kizara.

Based on the research that mentioned above shows that the study of the main characters contained in the literary works is important to be studied. Because the main character represents various characterization, personalities, social culture that can provide an indirect experience to the literary connoisseurs. As for this research the figure Kiritani Shuji is interesting and feasible to study based on Carl Gustav Jung's analytical psychology approach, because Shuuji's feelings and thoughts in dealing with events in his life presented in the form of monologues. This allows the researcher to examine his personality through the monologues of Shuuji's mind and feelings, Shuuji's dialogues with his friend and family, and the Shuji's reactions that appears in responding to his life events in the Nobuta wo Produce by Izumi Kizara. The focus of this article research is the study of personality types of main characters.

Jung distinguishes two main attitudes or personality orientations, namely extravert attitudes and introvert attitudes. According to him everyone has both attitudes, although both cannot be active at the same time (Feist, Feist and Robert 2013: 119). Attitude is determined by the direction of one's psychic energy. Extravert attitude refers to the person who directs his psychic energy to the outside world. Whereas, the person who directs psychic energy into himself is referred to as an introverted attitude (Hall and Lindzey 1993: 192). According to Jung, we do not quite understand a person's personality from extravert or introverted attitudes. That attitude is just a matter of where the psychic energy leads and has not explained how a person gets information from his environment. Here we will discuss its functions. Jung introduces four functions: thinking, feeling, intuiting and sensing. Thinking and feeling are included in rational groups because they work actively, evaluate and decide actions against objects encountered based on certain criteria.

Thinking is a logical activity that produces a series of ideas. Boeree (2010: 133), and Harbunangin (2016:82), explain that this function evaluates and decides information on the basis of certain rational and logical criteria of sizes and rules. Feeling evaluates and decides the information based on the feeling with the criteria of values, good or not good, like or dislike. So, the principle of feeling works not like thinking just different in the criteria. As for intuition and sensing function together into the group of irrational functions. Harbunangin defines irrational here as not actively evaluating and deciding but 'experiencing' the object (2016:82). In the meantime, Boeree said that the irrational function of meaning involved far here is perception, not an assessment of the information obtained from the senses (2010:133). The difference is, intuition experiences with a hunch or a conscience, experiencing something without going through the five senses, knowing without knowing how he can know. While sensing experiences something through the five senses (Harbunangin 2016:82).

Every human being has these four functions. The only difference is in proportion. Each of us must have a superior function, which we rely on and grow well within us; then we have a secondary function, which we are well aware of and greatly sustains our superior function; then we have a 
tertiary function, which is rather less developed and less conscious; and finally we have an inferior function, which develops very slowly and unconsciously that we often deny its existence. Most of us only develop one or two functions, but we should develop all four. Jung prioritizes the transcendence of these four opposing things (Boere 2010:134). Of the two types of personality and four functions, Jung classifies them into the following eight personality theories (Semium 2013:101-106):

1) The Extraverted Thinking Types are those who put the mind forward so that they may give the impression of cold or ignorance. Descriptions of their main properties are objective, rigid, and cold.

2) The Introverted Thinking Type that is the opposite of extravert thinkers, this type is strongly influenced by original ideas with subjective rationale, not with objective data (Ryckman 2013: 63). The main characteristic of the introverted type of thinker is theoretical, intelligent, and impractical.

3) The Extraverted Feeling Type. People with extravert feelings use objective data in performing judgments. The description of the main properties is vibrant, cheerful, and gentle (Semium 2013: 104).

4) The Introverted Feeling Type. The emotional expression of introverted people is lacking because the emotions within them are powerful and distressing to themselves. The main qualities of introverted people are silence, childishness, and ignorance.

5) The Extraverted Sensing Type. People who perceive extravert perceive external stimuli objectively as these stimuli are in reality. The description of the main properties is realistic, sensual and cheerful.

6) The Introverted Sensing Type. Introverted men are generally influenced by their prejudices of vision, taste, touch and so on. The main properties of people who introvert sensing type are passive, calm, and artistic.

7) The Extraverted Intuitive Type. Intuitive extraverted people are focused on the facts in the outside world. The main characteristic is fancy, fickle and creative.

8) The Introverted Intuitive Type. People with this type cannot be understood easily, and their ability to communicate effectively is very limited. The main characteristics of this type are mystical, dreamer, and unique.

Carl Gustav Jung states that man is always advancing or pursuing progress, from a less than perfect stage of development to a more perfect level. Humans also always try to achieve a higher level of differentiation. According to Jung, the goal of personality development is self-actualization, that is perfect differentiation and mutual harmony between all aspects of personality. Jung applies the duality aspect of his theory, his insight that no one is really introvert or otherwise. According to him, to achieve a healthy personality and strongly integrated then every aspect of personality must reach the level of optimal differentiation and development. The process to arrive in that direction by Jung is called the process of individuation or the process of self-discovery.

\section{METHOD}

This research uses qualitative approach with content analysis method. The literary approach used is a literary psychology approach using psychoanalytic theory based on Carl Gustav Jung's thought which is one of the derivatives of psychodynamic theory pioneered by Sigmund Freud. Data collection techniques in qualitative research is done through library studies and observations of things related to aspects of personality in the film series Nobuta wo Produce by Izumi Kizara.

The data collection procedure used to collect data in this study includes nine steps: (1) selecting and assigning the film to be investigated, the Nobuta wo Produce film series by Izumi Kizara, (2) establishing the focus of research on the personality of the main character , (3) watching the film repeatedly to gain a comprehensive understanding, (4) establishing content analysis as a research 
method, (5) establishing the approach of psychoanalytic approaches Carl Gustav Jung as a research approach, (6) conducting literature studies, observing aspects of personality in Nobuta wo Produce film series by Izumi Kizara, (7) analyzing data according to sub focus, (8) validating data, (9) making conclusions.

\section{RESULT AND DISCUSSION}

In the film series Nobuta wo Produce by Izumi Kizara who became the object of this research, researchers found sensing introvert, thinking introvert, introvert feeling, intuiting extravert, and feeling extravert on the Kiritani Shuuji's character. Based on the result of the research findings, 78 descriptions related to the personality type on the main character in Nobuta wo Produce film series by Kizara Izumi that can be explaines in the details thgough the following working table of the number of observation data recapitulation on the personality type.

TABLE 1. Working table of Number of Observation Data Recapitulation of Personality Type on The Main Character in The Film Series Nobuta wo Produce by Izumi Izara

\begin{tabular}{clcc}
\hline No. & Personality Types & $\begin{array}{c}\text { Number of Observation } \\
\text { Data (Quotes) }\end{array}$ & Percentage (\%) \\
\hline 1 & Sensing introvert & 4 & $5.13 \%$ \\
2 & Thinking introvert & 40 & $51.29 \%$ \\
3 & Intuiting introvert & 2 & $2.56 \%$ \\
4 & Feeling introvert & - & - \\
5 & Sensing ekstravert & - & - \\
6 & Thinking ekstravert & - & - \\
7 & Intuiting ekstravet & 3 & $3.84 \%$ \\
8 & Feeling ekstravert & 29 & $100 \%$ \\
\hline
\end{tabular}

\section{Sensing Introvert Type}

Sensing Introvert personality type on Kiritani Shuuji is found in episode five. Akira put Nobuko's artificial pig keychain at Shuuji's school bag and has invited the attention of female friends who are interested to have the same keychain, then Shuuji seizes this opportunity to demonstrate the potential Nobuko to them. Unmitigated, Shuuji also proposed selling this keychain in the Nobuta project. Although initially Akira and Nobuko hesitated, but Shuuji assured them that this key chain will be in demand. He also established Nobuko's heart to better sell it than just giving Nobuko's key chains for free. This is evident in the dialogue Shuuji in the phrase "じゃ,お金を払つて,始め

て,ありがたみがわかる ..." (People will appreciate it when they have to spend money).

Shuuji also gets ideas for spreading rumors about a key chain that can fulfill the expectations after hearing the mantra "ノブタパワー 注入!" (Nobuta power sign!) spoken by Nobuko in order for her keychain's to be sold. This is seen in the phrase"そう!これすげえ売れるんじゃん ,もしかして! どうするよ,これ!" (Really! Well it looks like it will be sold! What should we do?). In the situations described above, although the pretext for selling key chains to increase Nobuko's popularity, it seems a great desire on Shuuji to receiving benefits from the sale of Nobuta's keychain clearly seen. This is relevant to what Hiday explains about the greatness of a person with introverted sensing personality types in business, sales, making something that can make money (Hiday 2017: 108). 


\section{Thinking Introvert Type}

In the Nobuta wo Produce film series by Izumi Kizara who became the object of this research, researchers found data that describes the type of introvert thinking personality dominance on the Kiritani Shuuji's character. As a senior high school student, Kiritani Shuuji has a unique view of the world. He has a cold judgment in his life as seen in Shuuji's self-monologues in episode one, in the phrase “あれは思うようにこのようなすべてのゲームだ” (I am always convinced that the world is just a game). For Shuuji, the days of his school life are just insignificant repetitions because he goes through them without involving feelings. This is in accordance with the Semium's statement, that a person with introvert thinking type has superior functionality on the mind, so the side of the feelings of their lives is synthesized. They may give the impression of cold or dumb (Semium 2013: 100).

Shuuji does not really believe in his own judgment of the world, but he cannot live if he does not believe it. He lives with the goal of winning the life he considers the game. The formula for winning the game of life for Shuuji is with two things. First, living school life without involving feelings. Second, by maintaining its status without being hurt, that is by becoming a popular figure of cool, kind and friendly. Shuuji's desire to win the game of life is relevant to Hiday's explanation of how to motivate someone with introverted thinking personality types by challenging them (2017: 111). According to her, thinking children need an environment that gives victory over what he did. Environment with a competitive atmosphere can give a definite recognition of who wins and who loses (Hiday 2017: 125)

According to Hiday, someone with the function of thinking tends to be difficult to speak, let alone express the feelings or what is in his mind. Furthermore, he prefers to study alone rather than together in a discussion that requires conversation (2017: 122). Meanwhile, introverted attitudes with characteristics tend to be aloof and uncomfortable with the crowd, making someone with introverted thinking personality will feel uncomfortable in the crowd or collection of people in a long time. This appears on the character Kiritani Shuuji, the scene on episode one when Shuuji is listening to a friend who is talking in a group of male classmates. Although Shuuji is seen listening to the conversation seriously, but from through his monologue Shuuji reveals his true feelings that are not comfortable with what he is doing. This is evident in the phrase"お前なんか今後一切関係ねーだろっ てつっこみたくなるようなテレビで聞いた話しかしねー奴とか" (Actually, I'm lazy with people who talk about things they had heard from television viewing and others, I wanted to tell him, "hey, no need to take care of things that have nothing to do with you!").

Shuuji runs his days as a popular student in school. For that reason, not infrequently he must do things that are contrary to his personality dominated by introvert thinking type. Shuuji is required to act kindly and can mingle with all friends, karaoke together, chat group with friends, this confiscates Shuuji's energy. As someone with a dominant introvert attitude, Shuuji takes time for himself. He refreshed his self by touching willow trees on the seafront before leaving for school. For Shuuji, the willow tree is the only place that is comfortable and by touching it can give positive energy to him. Changes in expression on Shuuji who feel comfortable and energized after touching the willow tree is relevant to that expressed by Hiday about caliberation of an intuitive thinking is with non-humans, one of the best is to go green or go back to nature while chatting with animals or plants in nature (2017: 133).

Despite being a popular student and having many friends, Shuuji has no close friends. His friends do not even know when Shuuji's birthday is, because Shuuji never tells anyone. This is relevant to Semium's explanation, i.e. someone with dominant introvert thinking types develops a 
strong desire for privacy and is surprised when someone threatens to invade his remote area (2013: $10)$.

\section{Intuiting Introvert Type}

Someone with introverted attitudes and intuiting functions dominant have an optimistic personality, skillful at making concepts and ideas. In Nobuta wo Produce film series by Izumi Kizara's that became the object of this research, the researcher found data describing intuiting introvert personality type on Kiritani Shuuji's character. While acting as a producer in Nobuta's producing project, Shuuji spawned creative ideas that helped his self and his group solved the problem. Shuuji's first idea lies in the scene in episode one when Nobuko is challenged by Bando to read at Goyokudou's bookstore. The owner of Goyokudou's bookstore made a unique rule to limit people who wanted to read for free at his bookstore. One of the rules is just a handsome man and a beautiful woman who can read in the bookstore. Nobuta who looks creepy obviously did not enter the criteria. Therefore, Shuuji set a strategy for Nobuko to pass the challenge.

Utilizing Akira's treasures, Shuuji bought three lines of books on a bookcase and asked for permission to leave them while they were there. He also requested permission from the Goyokudou bookstore owner to be allowed to read the book there by reason of something he was looking for. Not to forget, Shuuji asked permission for Nobuko allowed to read there too. This strategy not only succeeded in making Nobuko successfully won the challenge from Bando, but he also managed to break the record of the longest reader in the Goyokudou bookstore and beat Mariko, the prettiest girl in school, reading record.

The next creative idea appears on episode two, when the mysterious figure painted Nobuko school uniform with the words "ブツ" (ugly). Shuuji is optimistic that the situation can benefit them. This is apparent in the phrase "いや,でも考えるようにってさ,チャンスだぞ" (Based on what we are planning there may be beneficial). The painted uniforms became a reason for Nobuko to get permission to wear free clothes to school as long as they do not have new uniforms. On the occasion he also used to change the appearance of Nobuko, ranging from hairstyles to clothing style. Shuuji also motivated Nobuko to come up with more confidence so that Nobuko performed stunningly with his new appearance at school.

The creative ideas of the character Shuuji above succeeded in producing a new breakthrough is the advantage of a person with intuiting functions that, according to Feist, Feist and Roberts have high creativity as they often add or subtract elements from the conscious sensation (2013: 123). Coupled with the introverted attitude that its source of energy comes from within itself, making a person with introvert intuiting personality type is awarded a surplus in original creative power. This is relevant to Hiday's statement, intuiting introverts endowed with creative quotient or creativity quotient. It is a type of intelligence that gives rise to wild ideas, leaving far behind its time (2017: 152). With his intuition, he tries to predict the possibilities that will happen in the future. And with that prediction, he will understand the risks faced.

\section{Intuiting Extravert Type}

Someone with ekstravert attitudes and intuiting functions dominant have a clever personality to look for opportunities and creatively create ideas with models of observation, imitation and modification (TTM). In the film series Nobuta wo Produce by Izumi Kizara who became the object of this research, researchers found data that describes the type of intuiting ekstravert personality on Kiritani Shuuji's character. According someone with intuiting functions, Feist and Feist have high creativity as often add or reduce elements of the conscious sensation (2013:123). Coupled with ekstravert attitudes whose source of energy comes from outside the environment makes a person with 
the dominant intuiting extravert type was awarded the ability to create fresh ideas with the TTM model. This capability appears to Shuuji in the scene in episode two, when permission to wear free clothes to school on whatever reason has been removed from school rules requires Nobuko to come to school in his uniform that has been painted "ブ ツ" by a mysterious figure.

In an effort to support Nobuko, Shuuji and Akira painted their uniforms with with the words " キザ" (showed off) for Shuuji's uniform, and the word "バカ" (foolish) for Akira's uniform. With the strategy of entering the class in sequence Shuuji first entered to show off his uniform to friends, then followed by the arrival of Akira, this strategy success of making classmates believe that painting school uniforms with strange writings will be a new trend, it appears in the phrase "ほ ら! 誰が真 似ていた.絶対ねはやせるぜ" (See! There are foolish persons who imitate me right! No doubt this will be popular!). Within days, painting school uniforms with strange words became a trend among the student at the time.

Nobuko school uniforms painted by mysterious figures inspired Shuuji to do the same on his uniform. If the painted Nobuko uniform is part of her coat, then Shuuji make modifications by painting the rear pocket of the back of his trousers. Shuuji's idea is called TTM, that is a fresh ideas with model of observation, imitation and modification as the advantages of intuiting extravert type.

\section{Feeling Extravert Type}

Someone with an extravert attitude and feeling function dominant possess an extravert feeling personality that looks sensitive for being granted social intelligence and enjoys behind-the-scenes roles like a coach. In Nobuta wo Produce film series by Izumi Kizara that became the object of this research, the researcher found the data depicting feeling extravert type of the character Kiritani Shuuji. On an afternoon in episode three, Shuuji returns home in a state of annoyance as Nobuko again refuses haircut. Arrived at home, Shuuji was surprised by his father who returned home more quickly than usual. Seeing the father with gloomy face, Shuuji gave attention by asking about father's day. Father explains to Shuuji about mafia-style suit that he wore to the office that day was disliked by his friends and superiors, it made him sad. Father gives Shuuji advice to wear clothes that he likes. This advice goes in the sentence follows, "大人になると, 人の目とから常識とか,よく 思われたいとか, 上司の顔色だとか, 御得意さんの心象だとか, 色んなもんが こう難いのし,掛かって,きな物を着れなくなっちゃうだもんな"(As an adult, you have to think about other people's views .. you should look good to others, also have to please your boss also make your customers feel good, you should consider everything. And soon you cannot wear clothes that you like).

Hearing father words, Shuuji feel pity of him and then allow him to put on mafia suit when attand parents meeting at Shuuji's school, although Shuuji also did not like the clothes. Dad's advice made him aware of his mistake before Nobuko, criticizing Nobuko who did not want to cut her hair by calling it like a monster. This is evident in monologue Shuuji, in the phrase "やつぱ, 人の趣 味とかコウチャコウチャ わないほうがいいの" (I should not have commented badly on others people looks).

On the next day, Shuuji corrected his mistake to Nobuko by borrow Akira's money to buy a suit of tacky clothes to wear as a condition for Nobuko want to cut her hair. Changes in attitude shown by Shuuji allows for experienced by someone with an extravert feeling personality type who has good emotional intelligence. This is relevant to Jung's explanation in Feist and Feist, namely the extraverted 
feeling people use objective data to take evaluation. They are not guided so much by their opinions, but by external values and standards accepted standards of judgment (2013: 122).

According to Hiday, someone with a feeling extraverts type enjoying his role behind the scenes as a trainer (coach) because he can listen to people, to see their problems and dig out their best potential and strive to make this potential for them (2017: 210). This is similar to that delivered by Semium regarding the ability of a feeling extraverted in considering value based on objective information (2013: 101). This is apparent in Shuuji's role as a producer in the Nobuta project.

Learned from the early experience when started producing Nobuko, Shuuji which was initially dominated by the thinking introverted types failed to persuade Nobuko to cut her hair, though with a logical reason. After returning home a comfortable place for Shuuji, extraverted personality types begin conscious and started dominate Shuuji when he saw his father sat for a suit mafia was not liked by his superiors in the office. After getting advice from the father, Shuuji also got useful leason from his father's experience by accepting Nobuko's heavy feelings to cut her hair. Finally, Shuuji willing to granted Nobuko's request for a haircut even hi doesn't like to doing that.

The starting point of feeling extravert type on Shuuji's personality activate is when he in progress of producing Nobuko. In order to change Nobuko's appearance, he did a research about the popular female teen dressing style by discussing with Mariko. Next, he invited Nobuko to choose the style that suits her. It happened in the phrase"人からどういう風に思われたいの?" (What do you want to see by others?). By giving Nobuko advice about style that everyone can accept, the next day Shuuji succeeds in making the whole school mesmerized by Nobuko's look that looks so cute.

In producing Nobuta, Shuuji does not force Nobuko to become a figure who is not herself. He reads the potential in Nobuko and maximizes it. Like when Nobuko became the presenter of a live broadcast lunch program. She still appears with a stuttering voice that is considered cute by her audience. Seeing friends reactions that entertained with Nobuko's nervous gestures as a presenter, Shuuji seized the opportunity to boost Nobuko's popularity. With the help of Akira, Shuuji creates various expressions, opening greetings and closing greetings for the live lunch program with the typical Nobuko style. It appears in the Shuuji's dialog when Akira suggest a closing sentence for Nobuko, "いや,なんかノブタがやるんだからさ,もっとごつこっつしたほゔ

いいよ" (It should be more funnier because Nobuta who would say it). Shuuji's strategy succeeded in making Nobuko names known and accepted by all circles at school so that her popularity rose significantly.

\section{CONCLUSION}

Based on the types of personality in the main character in the film series of Nobuta wo Produce by Izumi Kizara, it can be concluded that introvert thinking personality type tend to dominate the main character Kiritani Shuuji because it is the personality type that dominated him since childhood, this makes him grow into a cold person and put forward function of his mind. Although since childhood Shuuji accustomed to suppressing the function of his feelings, does not mean he can keep silent to see the injustice that occurred in front of his eyes. Shuuji actually became a leading figure in cracking down on the oppression committed by the Bando gang against Nobuko. By finding true friends who can accept him as the way he is, Shuuji's sensitivity is increasingly honed, so that at the end of the episode he can balance introverted thinking personality types and extravert personality types related to his personality wisely.

This research is recommended for teaching literature to teach personality types through film, especially to teach about psychological aspects which are included in film. In the world of Japanese language education, this research is recommended for the teaching of Japanese literature at the 
university level, for Nihon Bungaku subject (Japanese Literature) on the part of content explanation and fictional appreciation. The film series of Nobuta wo Produce by Izumi Kizara is also recommended for more in-depth study using the approach of psychology literature because the film is full of psychological aspects to be studied.

\section{REFERENCE}

Ariesta, F. \& Muliastuti1, L., 2017. Diskriminasi Ras Dalam Film The Help Karya Tate Taylor (Kajian Feminisme). BAHTERA: Jurnal Pendidikan Bahasa dan Sastra, 16(2), pp.47-55. Available at: http://dx.doi.org/10.21009/bahtera.162.04.

Boeree, George. (2010). Personality Theory Terjemahan Inyiak Ridwan Muzir. Jogjakarta: Prismasophie.

Endraswara, Suwardi. (2011). Metodelogi Penelitian Sastra (Epistemologi, Model, Teori, dan Aplikasi). Yogyakarta: PT. Buku Seru.

Feist, Jess, Gregory Feist, dan Tomi-Ann Roberts. (2013). Theories of Personality. Singapure: McGraw Hill Education.

Hall, Calvin S, dan Gardner Lindzey. (1993). Teori-Teori Psikodinamik (Klinis) Terjemahan A. Supratiknya. Yogyakarta: Kanisius.

Harbunangin, Buntje. (2016). Art \& Jung (Seni dalam Sorotan Psikologi Analitis Jung). Jakarta: Antara Publishing.

Husada, M., Ninuk Lustyantie, N., \& Nuruddin, N., 2017. Aktualisasi Diri Pada Tokoh Utama Dalam Novel Pasung Jiwa Karya Okky Madasari (Suatu Penelitian Psikoanalisis Sastra). BAHTERA : Jurnal Pendidikan Bahasa Dan Sastra, 16(2), 15-34. Available at: http://dx.doi.org/10.21009/bahtera.162.02.

Hiday, Miss. (2017). I Know You. Bekasi: STIFIn Institute.

Klerer, Mario. (2005). Introduction to the Literary Studies. New York: Routledge.

Nakamura, A., \& Tomoko M., 2014. 小説「野ブタ。をプロデュース」に見る自己愛（ペル ソナと自己プロデュース ) . 東京家政大学研究紀要, 54 (1)，85-93. Available at: http://ir.tokyo-kasei.ac.jp/meta-bin/mt-pdetail.cgi?cd=00002733.

Purnomosidhi, P., Nur Ahid, P,. \& Ninuk Lustyantie, N., 2018. Characterization of Woman Widowed in the Short Story Namanya, Massa, Tarian Hamil dan Penyair Bulan, and Norhayati (Literart Review Cross Reference). BAHTERA: Jurnal Pendidikan Bahasa dan Sastra, 17(1), (85-93). Available at: https://doi.org/10.21009/BAHTERA.171.9.

Rahmawati, Dian, L., 2013. Dinamika Kepribadian Tokoh Utama Novel Hubbu Karya Mashuri Berdasarkan Perspektif Jung. Jurnal Pendidikan Humaniora, 1 (2), 207-212. Available at: http://dx.doi.org/10.17977/jph.v1i2.4054.

Ryckman, Richard M. (2013). Theories of Personality. United States of America: Wadsworth Cengage Learning.

Semiun, Yustinus. (2013). Teori-Teori Kepribadian Psikoanalitik Kontemporer Jilid 1. Jakarta: Kanisisus.

Siswantoro. (2005). Metode Penelitian Sastra: Analisis Psikologis. Surakarta: Muhammadiyah University Press.

Trianton, Teguh. (2013). Film Sebagai Media Belajar. Yogyakarta: Graha Ilmu. 